\title{
Coupling Spore Traps and Quantitative PCR Assays for Detection of the Downy Mildew Pathogens of Spinach (Peronospora effusa) and Beet (P. schachtii)
}

\author{
Steven J. Klosterman, Amy Anchieta, Neil McRoberts, Steven T. Koike, Krishna V. Subbarao, \\ Hermann Voglmayr, Young-Joon Choi, Marco Thines, and Frank N. Martin
}

First, second, and ninth authors: United States Department of Agriculture-Agricultural Research Service (USDA-ARS), 1636 E. Alisal St., Salinas, CA; third author: University of California, Davis; fourth author: University of California Cooperative Extension, Salinas; fifth author: University of California, Davis, 1636 E. Alisal St., Salinas; sixth author: University of Vienna, Vienna; seventh and eighth authors: Goethe University Frankfurt am Main, Faculty of Biosciences, Institute of Ecology, Evolution and Diversity, D-60438 Frankfurt am Main, and Biodiversity and Climate Research Center (BiK-F), D-60325 Frankfurt am Main, Germany; and eighth author: BiK-F, Germany. Accepted for publication 12 June 2014.

\begin{abstract}
Klosterman, S. J., Anchieta, A., McRoberts, N., Koike, S. T., Subbarao, K. V., Voglmayr, H., Choi, Y.-J., Thines, M., and Martin, F. N. 2014. Coupling spore traps and quantitative PCR assays for detection of the downy mildew pathogens of spinach (Peronospora effusa) and beet $(P$. schachtii). Phytopathology 104:1349-1359.

Downy mildew of spinach (Spinacia oleracea), caused by Peronospora effusa, is a production constraint on production worldwide, including in California, where the majority of U.S. spinach is grown. The aim of this study was to develop a real-time quantitative polymerase chain reaction (qPCR) assay for detection of airborne inoculum of $P$. effusa in California. Among oomycete ribosomal DNA (rDNA) sequences examined for assay development, the highest nucleotide sequence identity was observed between rDNA sequences of $P$. effusa and $P$. schachtii, the cause

of downy mildew on sugar beet and Swiss chard in the leaf beet group (Beta vulgaris subsp. vulgaris). Single-nucleotide polymorphisms were detected between $P$. effusa and $P$. schachtii in the 18S rDNA regions for design of $P$. effusa- and $P$. schachtii-specific TaqMan probes and reverse primers. An allele-specific probe and primer amplification method was applied to determine the frequency of both $P$. effusa and $P$. schachtii rDNA target sequences in pooled DNA samples, enabling quantification of rDNA of $P$. effusa from impaction spore trap samples collected from spinach production fields. The rDNA copy numbers of $P$. effusa were, on average, $\approx 3,300$-fold higher from trap samples collected near an infected field compared with those levels recorded at a site without a nearby spinach field. In combination with disease-conducive weather forecasting, application of the assays may be helpful to time fungicide applications for disease management.
\end{abstract}

Downy mildews are widespread and destructive plant diseases caused by obligate oomycete pathogens. These pathogens produce large quantities of short-lived, asexual spores on host plant leaves which become airborne to cause secondary plant infections. Downy mildew on spinach (Spinacia oleracea), caused by Peronospora effusa (13), is a major disease constraint on production worldwide (16) and, in particular, in California and Arizona, where $\approx 85 \%$ of U.S. fresh-market spinach is produced (2). In the cool coastal Salinas Valley, CA, a region which produces roughly half of the fresh-market spinach grown in the state, downy mildew outbreaks are common. Although spinach downy mildew can usually be controlled with fungicide applications in conventional production, the disease can be devastating for organic spinach production, in which fungicide use is excluded. This, in turn, can accentuate inoculum availability for downy mildew epidemics in conventional production fields. The appearance of new races of $P$. effusa, which has occurred more frequently in recent years $(16,18)$, has complicated efforts aimed

Corresponding author: S. J. Klosterman;

E-mail address: Steve.Klosterman@ars.usda.gov

* The $\boldsymbol{e}$-Xtra logo stands for "electronic extra" and indicates that the online version contains two supplemental tables.

http://dx.doi.org/10.1094/PHYTO-02-14-0054-R

This article is in the public domain and not copyrightable. It may be freely reprinted with customary crediting of the source. The American Phytopathological Society, 2014 at breeding host resistance to downy mildew. The rapid appearance of these new races also emphasizes a need for alternative disease management practices.

Early and accurate warnings of the increases in airborne inoculum of plant pathogens can help manage disease outbreaks (35) and is recognized as a major grower priority (21). The ability to detect and quantify airborne spores may reduce costs associated with disease control in conventional production (number and frequency of fungicide applications) and contribute to reduced or delayed fungicide resistance development. Spore trapping systems such as Burkard traps, tapes, and impaction samplers, in combination with DNA amplification using conventional or realtime quantitative polymerase chain reaction (qPCR)-based methods, have been deployed successfully for the detection of plant pathogens in air samples $(9-11,17,19,29-31)$. The airborne powdery mildew pathogen, Erysiphe necator, was detected in vineyards using an impaction sampler and qPCR methodology (17). Similarly, detection and quantification were achieved for the airborne pine pitch canker pathogen, Fusarium circinatum (30), and Botryosphaeriaceae spp. that cause grapevine canker (31). PCRbased detection of Pseudoperonospora humuli in air samples from commercial hop yards has been useful in the timing of fungicide applications (22). These studies have highlighted the potential utility of spore trap and DNA-based assays in the analyses of airborne inoculum dispersal for economically important plant pathogens.

For the development of an assay for airborne downy mildew inoculum, a key requirement is species-specific detection. Al- 
though $\approx 50$ species have been reported to cause downy mildew on members of the Chenopodiaceae family (15), these have been classified as a single species, Peronospora farinosa (36). Observations of phylogenetic and morphological differences within $P$. farinosa $(12,13,33)$ as well as differences in host specificity (8) indicate that three formae speciales of $P$. farinosa may be more appropriately elevated into individual species, because they are not monophyletic. For example, phylogenetic and morphological analyses indicate that $P$. effusa is a distinct Peronospora sp. (13), although the designation as $P$. farinosa $\mathrm{f}$. sp. spinaciae remains in common usage to refer to the causal agent of downy mildew on spinach $(16,18)$.

Closely related downy mildew pathogens that do not cause disease on spinach could potentially interfere with an assay designed for specific detection of P. effusa. For example, Beta vulgaris subsp. vulgaris, which includes cultivated leaf beet (Swiss chard) and sugar beet groups (26), is infected by the downy mildew pathogen $P$. schachtii $(20,27)$, also known as $P$. farinosa $\mathrm{f}$. sp. betae (8). Sequence analyses indicate that $P$. schachtii is a distinct species (Y.-J. Choi, S. J. Klosterman, and M. Thines, unpublished data). P. schachtii does not cause disease on spinach, nor does $P$. effusa cause disease on $B$. vulgaris subsp. vulgaris $(8,27)$. However, $P$. schachtii is closely related to $P$. effusa, as determined by both phylogenetic analyses of sequences of the internal transcribed spacer (ITS) of the ribosomal DNA (rDNA $(13,24)$ and morphological studies (13). P. effusa and P. schachtii have overlapping geographic ranges, as in the Salinas Valley, CA, where spinach and Swiss chard are grown in proximity and harvested for their edible leaves. Because PCR methods rely on DNA-based detection, these techniques can increase the specificity of detection, potentially enabling differentiation between $P$. effusa and closely related species, such as $P$. effusa and $P$. schachtii. Peronospora sp.-specific PCR primers have been developed for $P$. aborescens infecting poppy (25), $P$. tabacina infecting tobacco (6), and $P$. belbarhrii infecting sweet basil (3). In each of these examples, the primers for development of these assays were designed from sequences of the ITS region in the rDNA.

The primary objectives of this study were to (i) develop a realtime qPCR assay for detection of $P$. effusa and (ii) apply the qPCR assay for the detection of $P$. effusa on impaction spore trap samples collected from fields. A single-nucleotide polymorphism (SNP) was the focal point for the development of $P$. effusa- and $P$. schachtii-specific TaqMan probes and primer sets for SNP allelefrequency determination, as previously applied in other systems $(4,23)$. In theory, nonspecific amplification of the nontarget SNP sequence is not expected when using the SNP-specific primers. In practice, however, there is typically nonspecific amplification (23). Therefore, SNP allele frequencies can be used to determine the difference in quantification cycle $(\mathrm{Cq})$ values between two amplified SNPs in two independent reactions and calculate the frequency of each SNP in a pooled DNA sample. The method was applied to determine the frequency of $P$. effusa and $P$. schachtii rDNA amplification from impaction spore trap samples collected from the field.

\section{MATERIALS AND METHODS}

Sequence analyses for assay development. The ribosomal RNA gene and ITS DNA sequences from $P$. effusa, $P$. schachtii, and those of other oomycetes were aligned and examined for differences and similarities using DNasis software (version 2.09; MiraiBio, Inc., Alameda, CA). These alignments included sequences available at the National Center for Biotechnology Information (NCBI). For additional sequence comparisons, DNA from downy-mildew-infected leaves was amplified using primers UF1 (5'-TGAATGCGCATCGTGC-3') and UR2 (5'-AGATGCCA CACAACCGAAG-3'), designed to amplify the rDNA sequence spanning a portion of the 18S RNA gene, ITS1, 5.8S RNA gene, and a portion of ITS2 from Peronospora spp. DNA was extracted from downy-mildew-infected leaf tissue using a NucleoSpin Plant II kit (Machery-Nagel, Bethlehem, PA). The rDNA sequence was amplified using an MJ Research PTC200 thermal cycler (BioRad, Hercules, CA) using $200 \mathrm{nM}$ each of primers UF1 and UR2 and $1 \times$ GoTaq Mix (Promega Corp., Madison, WI). The reaction conditions consisted of an initial denaturation at $94^{\circ} \mathrm{C}$ for $3 \mathrm{~min}$ followed by 35 cycles of $94^{\circ} \mathrm{C}$ for $30 \mathrm{~s}, 60^{\circ} \mathrm{C}$ for $30 \mathrm{~s}$, and $72^{\circ} \mathrm{C}$ for $30 \mathrm{~s}$. A final extension at $72^{\circ} \mathrm{C}$ was for $5 \mathrm{~min}$. The PCR products were cloned into pCR4.0-TOPO (Life Technologies, Carlsbad, CA) and sequenced (Eton Biosciences, San Diego, CA). All of those listed in Supplemental Table 1 were sequenced and submitted to GenBank.

Primer and probe design for TaqMan assays. TaqMan probebased assays were designed for SNP allele-frequency determination (23) using the allele-specific probe and primer amplification assay (ASPAA) method (4). For the $P$. effusa-specific assay, forward primer AS1 (5'-GCACCTACCGATTGAATGAC-3') was combined with the FAM dye-labeled TaqMan-minor-groovebinding (MGB) probe with a nonfluorescent quencher (NFQ) Pef1 (5'FAM-ACTGTGACCCCGCT-MGB-NFQ-3') and a $P$. effusa-specific reverse primer PeR1 with the SNP (bold) and a mismatch (italics and underlined) incorporated at the $3^{\prime}$ end $\left(5^{\prime}\right.$ CGCTCGCAATTACTTCCAG-3'). The P. schachtii-specific assay consisted of AS1 and the VIC dye-labeled TaqMan-minor-groovebinding (MGB) probe Pbel (5'VIC-ACTGTGACCCCGTTMGB-NFQ-3') combined with reverse primer PbR1 containing the $P$. schachtii-specific SNP (bold) and a mismatch (italics and underlined) incorporated at the $3^{\prime}$ end (5'-TCCGCTCGCAAT TACTCCAAA-3'). Probes were labeled differently with FAM or VIC reporter dyes for use in multiplexing but the multiplexed reaction was deemed unusable due to the nonspecific amplification between the two sets of probes at higher $\mathrm{Cq}$ values (data not shown). A single base pair was added to the $3^{\prime}$ end of the original primers to generate P1EF (5'-GCACCTACCGATTGAA TGACT-3') and P1BF (5'-GCACCTACCGATTGAATGACA-3') in replacement of forward primer AS1.

Assay efficiencies and detection limits. All real-time qPCR experiments in this study were performed using a LightCycler 480 II (Roche Diagnostics, Basel, Switzerland). TaqMan assay efficiencies were determined using a 10-fold dilution standard curve from 600,000 copies to 600 copies using PstI-linearized pCR4.0-TOPO (Life Technologies) containing the PCR products from $P$. effusa or $P$. schachtii that had been generated with primer pair AS1 and PeR1 or with pair AS1 and PbR1, respectively. Limits of detection were determined by performing serial 10 -fold dilutions of genomic DNA from $1 \mathrm{ng}$ to $1 \mathrm{fg}$ and a standard curve of 600,000 to 6 copies of the linearized plasmid containing the respective rDNA fragment.

Tests of TaqMan assay specificity. Specificity of the TaqMan assays was examined by testing both the $P$. effusa- and $P$. schachtii-specific assays against DNA samples of downy-mildewinfected plant leaves obtained from multiple sources (Table 1). Controls included leaf DNA samples from noninfected beet or spinach. DNA was extracted for this purpose using either the NucleoSpin Plant II kit (Machery-Nagel) or a previously described method (28). All DNA extracted for this purpose was quantified with a Qubit fluorometer (Life Technologies) and the Qubit dsDNA BR Assay Kit, using $2 \mu \mathrm{l}$ of extraction per reaction. The integrity of Peronospora spp. DNA from the infected leaf samples tested was confirmed by qPCR using the rDNA primer pair UF1 and UR1 in a reaction containing $200 \mathrm{nM}$ each primer, $1 \times$ IQ SYBR Green (Bio-Rad) and 2 ng DNA with a reaction profile of $95^{\circ} \mathrm{C}$ for $10 \mathrm{~min}$ followed by 40 cycles of $95^{\circ} \mathrm{C}$ for $30 \mathrm{~s}$, $50^{\circ} \mathrm{C}$ for $30 \mathrm{~s}$, and $72^{\circ} \mathrm{C}$ for $30 \mathrm{~s}$ using the LightCycler $480 \mathrm{II}$ (Roche Diagnostics). Melt peaks were examined to confirm amplification of the correct product. 
Downy mildew pathogenicity tests. To test whether other local downy mildews from non-spinach Chenopodiaceae plants could infect spinach, a series of inoculation experiments were conducted. Symptomatic plants exhibiting abaxial sporulation were collected near spinach-growing areas in Monterey County (lambsquarters weed, Chenopodium album; and nettleleaf goosefoot weed, C. murale) and neighboring Santa Cruz County (commercial Swiss chard, B. vulgaris subsp. vulgaris; and commercial epazote, Dysphania ambrosioides). A set of 10 differential spinach cultivars used for identifying races of spinach downy mildew, including the universally susceptible 'Viroflay' (18), were used in the experiments. Fungicide-free seed of the 10 cultivars was planted into two $25-\mathrm{by}-50-\mathrm{cm}^{2}$ plastic trays containing Sunshine mix number 4 (Sun Gro Horticulture, Agawam, MA). Seed were arranged in five rows per tray and 25 seed per row. Plants were inoculated when 21 days old. Sporangial inoculum was prepared by agitating collected, diseased leaves in cold $\left(4^{\circ} \mathrm{C}\right)$ water, filtering the mixture through a layer of cheesecloth, and adjusting inoculum concentration to $\approx 1 \times 10^{4}$ sporangia $/ \mathrm{ml}$. Plants were inoculated with a hand-held mister until runoff and incubated in a dew chamber $\left(100 \%\right.$ relative humidity, $\left.18^{\circ} \mathrm{C}\right)$ for $24 \mathrm{~h}$ (18). Plants were then moved to a humidity chamber that was periodically misted (3-min duration every $12 \mathrm{~min}$ ) and examined daily for chlorotic symptoms and signs of the downy mildew. Inoculations were completed two times, with the exception of the nettleleaf goosefoot downy mildew sample, which did not provide enough inoculum for a second inoculation.

Spore trap sample collection. Custom solar- or batterypowered impaction spore traps, similar to Rotorods (Sampling Technologies Inc., Minnetonka, MN), for detection of windborne inoculum were obtained from Dr. Walt Mahaffee (United States Department of Agriculture-Agricultural Research Service [USDAARS], Corvallis, OR). The application of similar traps in the field for detection of Erysiphe necator was described previously (17). Pairs of 1.2-by-40-mm stainless-steel rods were cut from welding wire (316LSi stainless steel; Harris Products Group, Mason, OH), and coated with a layer of high-vacuum grease (Dow Corning, Midland, MI) using gloved hands. The rods were positioned on the rotating arm $\approx 53 \mathrm{~cm}$ above the soil surface at each sampling site. To ensure that the rods from the impaction spore traps were not contaminated by spores trapped in residual grease and debris, the rotating arm of the spore trap that holds the impaction rods was washed with isopropanol and wiped with a clean paper towel after each sampling, before replacement with new clean rods. The

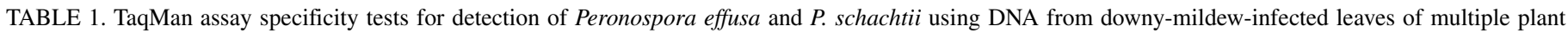
hosts

\begin{tabular}{|c|c|c|c|c|c|}
\hline Host plant sample (species or common names) & Pathogen & Sample location $^{\mathrm{a}}$ & Year & $\begin{array}{l}\text { P. effusa assay } \\
(\mathrm{Cq} \pm \mathrm{SD})^{\mathrm{b}}\end{array}$ & $\begin{array}{c}\text { P. schachtii assay } \\
(\mathrm{Cq} \pm \mathrm{SD})\end{array}$ \\
\hline Spinacia oleracea $\left(\right.$ spinach) ${ }^{\mathrm{c}}$ & Peronospora effusa & Imperial County & 2012 & $19.95 \pm 0.07$ & $30.10 \pm 0.09$ \\
\hline S. oleracea & P. effusa & San Benito County & 2012 & $19.60 \pm 0.19$ & $30.61 \pm 0.16$ \\
\hline S. oleracea & P. effusa & San Benito County & 2012 & $19.28 \pm 0.17$ & $30.38 \pm 0.15$ \\
\hline S. oleracea & P. effusa & Monterey County & 2012 & $22.25 \pm 0.16$ & $33.54 \pm 0.50$ \\
\hline Beta vulgaris subsp. vulgaris (beet) ${ }^{\mathrm{d}}$ & P. schachtii & Monterey County & 2012 & $34.66 \pm 0.23$ & $19.92 \pm 0.13$ \\
\hline B. vulgaris (beet) & P. schachtii & Santa Maria County & 2012 & $37.09 \pm 0.42$ & $21.03 \pm 0.15$ \\
\hline B. vulgaris (Swiss chard) & P. schachtii & Santa Cruz County & 2012 & $36.87 \pm 0.93$ & $19.89 \pm 0.08$ \\
\hline B. vulgaris (Swiss chard) & P. schachtii & Monterey County & 2012 & $36.60 \pm 0.45$ & $20.11 \pm 0.13$ \\
\hline Atriplex oblongifolia (oblong orache) & Peronospora sp..$^{\mathrm{e}}$ & Germany & 2005 & - & NT \\
\hline A. oblongifolia & Peronospora sp. & Germany & 2004 & - & NT \\
\hline A. patula (spear saltbush) & P. minor & Austria & 2011 & - & - \\
\hline A. patula & P. minor & Austria & 2005 & - & - \\
\hline A. prostrata (triangle orache) & P. atriplicis-hastatae & Germany & 2003 & - & - \\
\hline A. prostrata & P. atriplicis-hastatae & Germany & 2003 & - & - \\
\hline A. sagittata (hoary orache) & Peronospora sp..$^{\mathrm{e}}$ & Germany & 2002 & - & - \\
\hline Bassia scoparia (burning bush) & P. kochiae-scopariae & Germany & 1998 & - & - \\
\hline B. scoparia & P. kochiae-scopariae & Germany & 1996 & - & - \\
\hline B. scoparia & P. kochiae-scopariae & Austria & 2011 & - & - \\
\hline Chenopodium album (lamb's quarters) & P. variabilis & Germany & 2008 & - & - \\
\hline C. album & P. variabilis & Germany & 2007 & - & - \\
\hline C. album & P. variabilis & Austria & 2011 & - & - \\
\hline C. album & P. variabilis & Monterey County & 2013 & - & - \\
\hline C. bonus-henricus (good King Henry) & P. boni-henrici & Austria & 1991 & - & - \\
\hline C. bonus-henricus & P. boni-henrici & Italy & 2012 & - & $34.08 \pm 0.50$ \\
\hline C. bonus-henricus & P. boni-henrici & Austria & 2000 & - & - \\
\hline C. polyspermum (manyseed goosefoot) & P. chenopodii-polyspermi & Germany & 1998 & - & - \\
\hline C. polyspermum & P. chenopodii-polyspermi & Germany & 2004 & - & NT \\
\hline C. polyspermum & P. chenopodii-polyspermi & Austria & 2011 & - & - \\
\hline Dysphania ambrosioides (epazote) & Peronospora sp. ${ }^{\mathrm{f}}$ & Santa Cruz County & 2013 & - & - \\
\hline Rumex acetosa (garden sorrel) & P. rumicis & Germany & 2008 & - & $22.80 \pm 0.00$ \\
\hline R. acetosa & P. rumicis & Austria & 2011 & - & $25.12 \pm 0.19$ \\
\hline R. acetosa & P. rumicis & United Kingdom & 2011 & - & $21.10 \pm 0.21$ \\
\hline Spergula arvensis (corn spurry) & P. obovata & Germany & 2003 & - & - \\
\hline S. arvensis & P. obovata & Germany & 2005 & - & - \\
\hline S. arvensis & P. obovata & Austria & 2008 & - & - \\
\hline S. arvensis & P. obovata & Austria & 2011 & - & - \\
\hline
\end{tabular}

a Counties located in California in the United States.

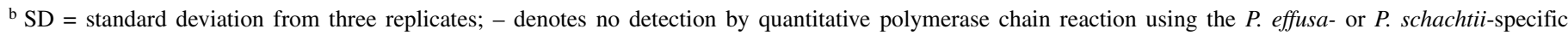
TaqMan assays with DNA from infected leaf tissue (quantification cycle [Cq] values $>38$ were considered negative for these specificity tests); and NT $=$ not tested.

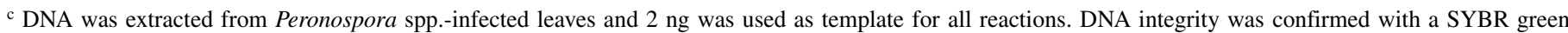
assay (see Materials and Methods), and the Peronospora spp. ribosomal DNA of the samples from Spinacia oleracea and B. vulgaris subsp. vulgaris and the single one from $D$. ambrosioides were cloned and sequenced.

${ }^{\mathrm{d}}$ B. vulgaris subsp. vulgaris includes the cultivated beet groups of table beet and Swiss chard.

e Phylogenetically different from Peronospora species known previously on Atriplex spp. (12).

f The Peronospora sp. on D. ambrosioides is phylogenetically different from other Peronospora spp. (12). 
rods were collected at $\approx 48$ - or 72 -h intervals and placed into $1.75-\mathrm{ml}$ screw-cap centrifuge tubes and stored at $4^{\circ} \mathrm{C}$ until DNA extraction. Rods were not reused.

Spore traps were placed at three separate sites for this study. First, spore traps were placed near a spinach field during 1 through 8 September 2012, by Watsonville, in Santa Cruz County, CA. The other two sites in Monterey County, designated as Salinas and Soledad, were monitored during 13 March to 3 April 2013. At the Salinas site, located $\approx 35 \mathrm{~km}$ from the Soledad site, two spore traps were placed side by side $(\approx 0.5 \mathrm{~m}$ apart $)$ in a USDA-ARS equipment yard where there were no nearby spinach fields during the period of study. At the Soledad site, one spore trap was placed at the north end and one $\approx 750 \mathrm{~m}$ apart at the south end of a downy-mildew-infected spinach field.

DNA extraction from spore trap impaction rods. The NucleoSpin Plant II kit (Machery-Nagel) was used to extract DNA from each 40-mm stainless-steel spore trap rod individually. A single $1.5-\mathrm{ml}$ microcentrifuge tube cap full $(\approx 300 \mathrm{mg})$ of acidwashed 425 - to $600-\mu \mathrm{m}$ glass beads (Sigma Aldrich, St. Louis) and $300 \mu \mathrm{l}$ of buffer PL1 were added to each tube and vortexed horizontally for $5 \mathrm{~min}$, incubated at $65^{\circ} \mathrm{C}$ for $10 \mathrm{~min}$, and vortexed once again horizontally for $5 \mathrm{~min}$. After a brief centrifugation, a 100- $\mu$ l aliquot of chloroform was added, mixed by vortexing, and centrifuged for $15 \mathrm{~min}$. The supernatant was applied to a spin column and further processed following the manufacturer's protocol, with the exception that DNA elution was performed with one $65-\mu \mathrm{l}$ aliquot of buffer PE incubated at $65^{\circ} \mathrm{C}$ for $5 \mathrm{~min}$. The elution $(5 \mu \mathrm{l})$ was quantified with the Qubit fluorometer using the Qubit dsDNA HS Assay Kit (Life Technologies), which has a detection range of $10 \mathrm{pg}$ to $100 \mathrm{ng} / \mu \mathrm{l}$.

Cloning and sequencing of PCR products obtained from spore traps. The Peronospora-conserved primers UF1 and UR1 were used to amplify sequences from selected spore trap samples. The PCR product was sequenced directly but some selected qPCR products were purified and cloned into pCR4.0-TOPO (as described above) and sequenced in both directions with T7 and T3 universal primers (Eton BioSciences).

qPCR with spore trap samples. The qPCRs were run in triplicate using one DNA extraction per spore trap. Reaction volumes of $20 \mu \mathrm{l}$ contained $200 \mathrm{nM}$ probe, $900 \mathrm{nM}$ each primer, 1× TaqMan Environmental Master Mix 2.0 (Life Technologies), and $2 \mathrm{ng}$ of DNA or $6 \mu \mathrm{l}$ of eluate when the DNA concentration was $<0.33 \mathrm{ng} / \mu \mathrm{l}$. The LightCycler 480 II (Roche Diagnostics) with LightCycler 480 software (release 1.5.0) and the Fit Points Absolute Quantification Analysis was used to conduct the assays with a reaction profile of $10 \mathrm{~min}$ at $95^{\circ} \mathrm{C}$ initial denaturation followed by 40 cycles of $95^{\circ} \mathrm{C}$ for $10 \mathrm{~s}$ and $60^{\circ} \mathrm{C}$ for $30 \mathrm{~s}$. Both assays were run on each sample and the relative frequency of the $P$. effusa SNP (allele 1) was calculated based on the following equation, as described (23): frequency of allele ${ }_{1}=1 /\left(2^{\Delta \mathrm{Cq}}+1\right)$ where $\Delta \mathrm{Cq}=(\mathrm{Cq}$ of allele $1-$ specific PCR $)-\left(\mathrm{Cq}\right.$ of allele ${ }_{2}-$ specific PCR). The use of absolute quantification for calculating the relative frequency of the amounts of $P$. effusa and $P$. schachtii is possible because the TaqMan assays used for each have nearly identical efficiencies, at 99 and $102 \%$, respectively.

Standard curves were used to determine copy number in spore trap extractions. The standard curves were used to establish thresholds of 0.8 for the P. effusa assay and 2.0 for the P. schachtii assay, which gave the slightly higher efficiency. After initial testing, a 600,000 rDNA copy standard was run on each plate using these standard thresholds, and the same slope and $y$-intercept were used for the linear regressions for the copy number calculations (3.378 slope, $43.77 y$-intercept for the $P$. effusa assay and 3.226, 41.92 for the $P$. schachtii assay).

Analyses of qPCR inhibition. The effect of spore trap grease on PCR inhibition was analyzed by comparing the amplification of rDNA in the presence or absence of spore trap extract using $P$. effusa genomic DNA as template. The DNA extractions were performed as described for the DNA extraction on impaction spore trap rods coated in grease. Buffer elution was performed with a single $65-\mu \mathrm{l}$ buffer aliquot on either a single column or as elutions on two columns representing two separate rod extractions with the same $65-\mu \mathrm{l}$ buffer volume. $P$. effusa genomic DNA was diluted 10 -fold, $100 \mathrm{pg}$ to $100 \mathrm{fg}$. qPCR was performed on the genomic DNA or genomic DNA combined with $6 \mu$ of eluate from either single-rod extractions or extractions from two rods. Differences in $\mathrm{Cq}$ values between the single-rod extraction or two-rod extraction were compared.

To calculate the amount of PCR inhibition on the impaction spore trap samples, the copy number standard curve generated initially was modified by adjusting the threshold so that the efficiency used in the standard curve for the calculation of the DNA copy number amplification matched the efficiency of the genomic DNA standard curve plus inhibitors (91.6\%). Then, the slope and $y$-intercept from the changed copy number curve was applied to all of the spore trap samples.

Spore counts under microscopy. Fresh spores of $P$. effusa were obtained for counting under light microscopy 1 or 2 days after collection from greenhouse-grown infected spinach leaf samples (grown and inoculated as described above). A single human hair, $\approx 2 \mathrm{~cm}$ in length, was brushed across the gray spore masses typical of $P$. effusa on the underside of the infected leaf to collect spores. Decreased numbers of spores could be obtained by rubbing only the tip of the hair or increased numbers by rubbing the entire length of the hair in the spore masses. Spores were counted along the length of the hair and immediately placed in microfuge tubes containing a steel rod coated with grease. Sporangiophores were rarely encountered on the hairs in this process and, if present, the sample was discarded. This was repeated 20 times to obtain 20 samples differing in spore number. These 20 samples were used to correlate $P$. effusa spore counts by microscopy and DNA copy number determined by qPCR. Negative control samples were prepared by DNA extraction from a grease-coated rod in the presence of a single hair, also of $\approx 2 \mathrm{~cm}$ in length.

Data analysis. Linear regression analysis was used to evaluate the relationships between the DNA concentration and $\mathrm{Cq}$ values and between the numbers of $P$. effusa spores counted by microscopy and DNA copy number.

\section{RESULTS}

Sequence analyses for TaqMan assay probe and primer development. Initial analyses were aimed at developing a $P$. effusaspecific probe and primer set by focusing on the ITS 1 and 2 regions of the rDNA. ITS sequence alignments did not reveal potential primer sites that could uniformly distinguish between $P$. effusa from all related oomycetes surveyed (data not shown). However, alignments of the upstream (5') 18S ribosomal RNA gene (18S rDNA) revealed potential target sequences that could be used in probe and primer development to differentiate $P$. effusa from related oomycetes. The alignments of a 67-bp region of the $P$. effusa 18S rDNA from representative oomycetes revealed sequence variation between $P$. effusa and other Peronospora spp. and oomycetes (Fig. 1). BLASTn analysis (1) of the NCBI nonredundant database with the 67-bp $18 \mathrm{~S}$ rDNA sequence of $P$. effusa yielded only two sequences with $100 \%$ identity (accessions AF528560.1 and AF528559.1), both of which were derived from P. effusa (13).

The highest interspecies sequence homology observed between the partial 18S rDNA sequences in this analysis (Fig. 1) was recorded between $P$. effusa and $P$. schachtii (97\%), although two SNPs were identified in the $18 \mathrm{~S}$ rDNA sequence to differentiate $P$. effusa from $P$. schachtii (Fig. 1). The rDNA sequences of $P$. effusa deposited in the GenBank database are often partial, with only the two P. effusa accessions mentioned above with the up- 
stream 18S rDNA area containing the two SNPs for further evaluation. Therefore, 10 additional rDNA sequences from $P$. effusa and 10 additional sequences from $P$. schachtii were obtained, revealing the presence of the same two SNPs in all of the sequences. The single SNP difference depicted in Figure 1 with an asterisk was incorporated into the sequence of the reverse primer (PeR1) and probe (Pef1) for the purpose of generating a $P$. effusa-specific TaqMan assay. P. schachtii-specific reverse primer $(\mathrm{PbR} 1)$ and the probe (Pbe1) were prepared similarly. The two assays were used in two separate reactions for SNP allelefrequency determination (23). The reverse primers and probes for both assays were designed to intentionally overlap (Fig. 1) and a mismatch was introduced following the ASPAA method described by Billard et al. (4) to enhance species-specific detection.

Assay efficiencies, limits of detection, and specificity. Standard curves for each of the TaqMan assays designed for $P$. effusa or $P$. schachtii detection are shown in Figure 2. For the $P$. effusa TaqMan assay, the limit of detection was $10 \mathrm{fg}$ of genomic DNA or 60 copies on the standard curve (Fig. 2A). The TaqMan assays used for each had nearly identical efficiencies, at 99 and $102 \%$, respectively. When determining efficiency level of the VIC dyelinked $P$. schachtii assay, there was increased background interference at the highest $\mathrm{Cq}$ values and, therefore, the 60 copy number was not included in this curve (Fig. 2B). However, the limit of detection of the $P$. schachtii TaqMan assay was also determined at 10 fg using a $P$. schachtii genomic DNA standard.

Although the assays were designed for species specificity, nonspecific amplification of $P$. schachtii DNA was evident (Fig. 3 ) using the $P$. effusa-specific assay on a range of plasmid concentrations containing the rDNA fragment. Additional forward primers P1EF and P1BF, incorporating the second SNP difference (Fig. 1, not labeled with an asterisk) between $P$. effusa and $P$. schachtii were tested in an effort to further increase specificity of amplification. Tests of these primers also resulted in nonspecific amplification of the $18 \mathrm{~S}$ rDNA sequence (data not shown).

Specificity testing of the TaqMan assays. Further specificity tests of the TaqMan assays using both the $P$. effusa-specific and $P$. schachtii-specific probe and primer sets were conducted on a range of downy-mildew-infected leaf samples from different geographic locations, including those outside of California (Table 1). P. schachtii-nonspecific amplification was observed when using the $P$. schachtii-infected leaf tissue DNA extract as template (Table 1). Aside from that, the $P$. effusa-specific assay was specific when tested against a range of other downy mildew DNA samples extracted from various infected hosts, including C. album (lambsquarters), a common weed in and around spinach fields in the Salinas Valley. Application of the TaqMan assays with DNA template from $C$. album infected with $P$. variabilis (12) did not yield a detectable DNA amplification signal using either the $P$. effusa- or $P$. schachtii-specific DNA probes and primer pairs (Table 1). Among the infected leaf samples tested, all of those from Rumex acetosa (garden sorrel) infected with $P$. rumicis were positive when tested with the $P$. schachtii-specific TaqMan assay, with a $\mathrm{Cq}$ range of 21.1 to 25.12 (Table 1). DNA samples derived from noninfected spinach and beet were negative for detection using either the $P$. effusa- or $P$. schachtii-specific TaqMan assay (data not shown)

Pathogenicity tests of downy mildew isolates on spinach. Because the TaqMan assays for $P$. effusa or P. schachtii were designed for species-specific DNA amplification, the assays would exclude pathogens from other hosts which could potentially contribute to disease on spinach. All of the differential cultivars tested, including the universal susceptible spinach Viroflay, exhibited no downy mildew symptoms and no sporulation when inoculated with Peronospora spp. isolates collected from the weeds (lambsquarters and nettleleaf goosefoot) or from the cultivated plants (Swiss chard and epazote) (Supplemental Table 2). All inoculations resulted in the same lack of disease.

Detection of downy mildew inoculum from spore traps. The configurations of primers and probes for specific detection of either P. effusa or P. schachtii (Fig. 1) were used for the experiments to test application of the TaqMan assays with spore trap samples obtained from the field. Initial tests of the impaction spore trap samplers for the detection of $P$. effusa and $P$. schachtii were conducted at a location near a commercial spinach field by Watsonville, CA. No downy mildew infection of the spinach field was observed during this period but $\mathrm{Cq}$ values of $25.55 \pm 0.12$ standard deviation (SD) and $31.38 \pm 0.19 \mathrm{SD}$, such as those from trap samples collected on 8 September 2012, suggested that the traps were positive. To assess whether $P$. effusa or $P$. schachtii was present, DNA was extracted from the rods from these two trap samples and sequenced, revealing the 67- or 69-bp 18S rDNA

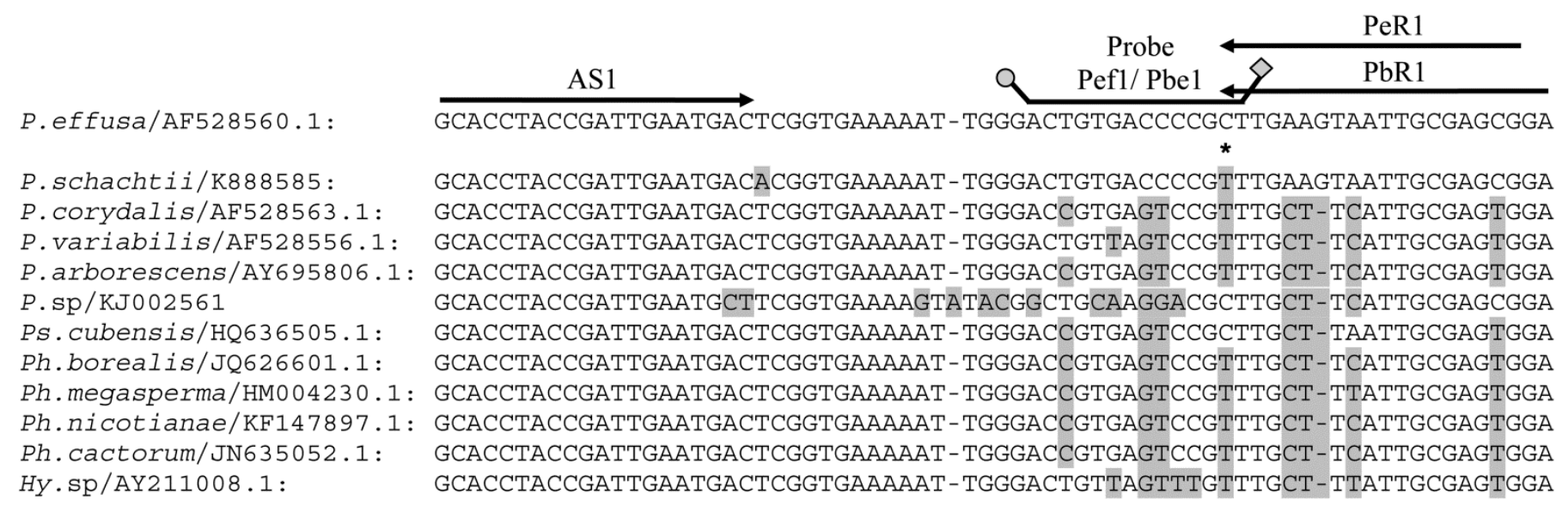

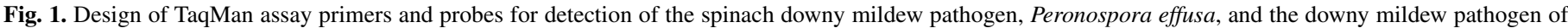

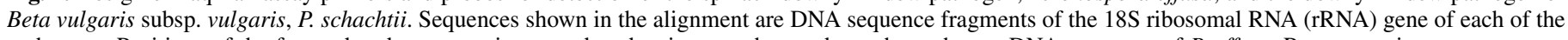

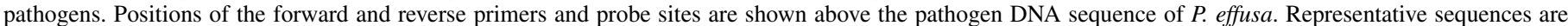

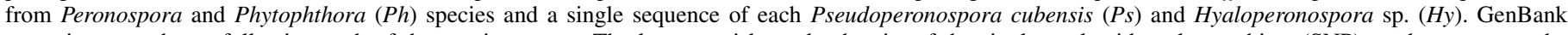

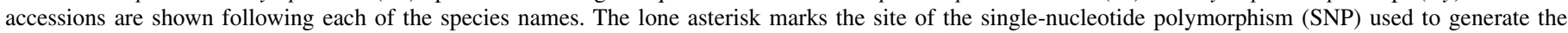

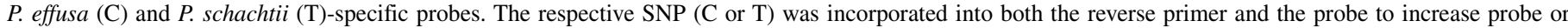

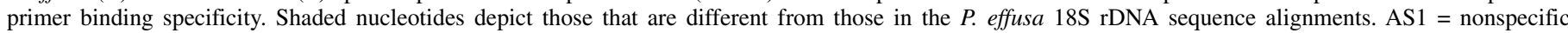

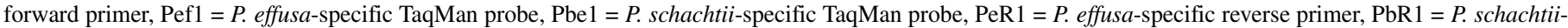

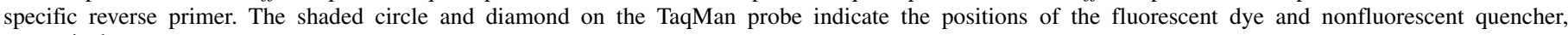
respectively. 
sequences identical to those of P. effusa and P. schachtii (Fig. 1), respectively. All of the no-DNA template control samples prepared with grease-coated rods and extracted for DNA were negative for amplification (data not shown).

Because the primer-probe combination for $P$. effusa yielded a detection signal for $P$. schachtii from qPCRs using the rDNA fragment from $P$. schachtii- (Fig. 3) or P. schachtii-infected leaf tissue DNA (Table 1), dual qPCR analyses were subsequently performed on each sample. The differences in $\mathrm{Cq}$ values were determined for the two independent PCRs and the frequency of nonspecific amplification was calculated as described in Materials and Methods, following the method of Germer et al. (23) shown in Figure 4. Multiplication of frequency by the total P. effusa $18 \mathrm{~s}$ rDNA copy number detected for each trap sample enabled calculation of the $18 \mathrm{~S}$ rDNA copy number of $P$. effusa for each sample (Table 2). The average 18S rDNA copy number for $P$. effusa detected at the Soledad site on both traps across all sampling dates was 785,723 . In contrast, the average rDNA copy number for $P$. effusa was 236, detected at the Salinas site, where the traps were not placed near a downy-mildew-infected spinach field. Based upon these average values, the amount of $P$. effusa DNA detected was $\approx 3,300$-fold higher at the Soledad site during the entire period of investigation (Table 2).

Though spore traps were not placed near downy-mildewinfected fields that contained cultivated beet groups, the average frequency of $P$. schachtii $18 \mathrm{~S}$ rDNA amplification from the Salinas site spore trap samples was 0.51 and 0.30 for $P$. effusa (including detection dates with values of 0 in the average calculation) during the sampling period (Table 2). There were no nearby spinach fields at the Salinas site during the sampling period. However, the Salinas spore trap site was located $\approx 1.5 \mathrm{~km}$ north of a site with known downy mildew infections of Swiss chard during the sampling period.

Correlation between DNA copy number of $P$. effusa and spore counts. The correlation between DNA copy number of $P$. effusa detected and actual spore counts of $P$. effusa from microscopy analyses (Fig. 5) provided an estimate of the number of spores detected on the steel impaction rods obtained from the field. Correlation was observed $\left(R^{2}=0.7603\right)$ between DNA copy number of $P$. effusa derived from a standard curve of the ampli-
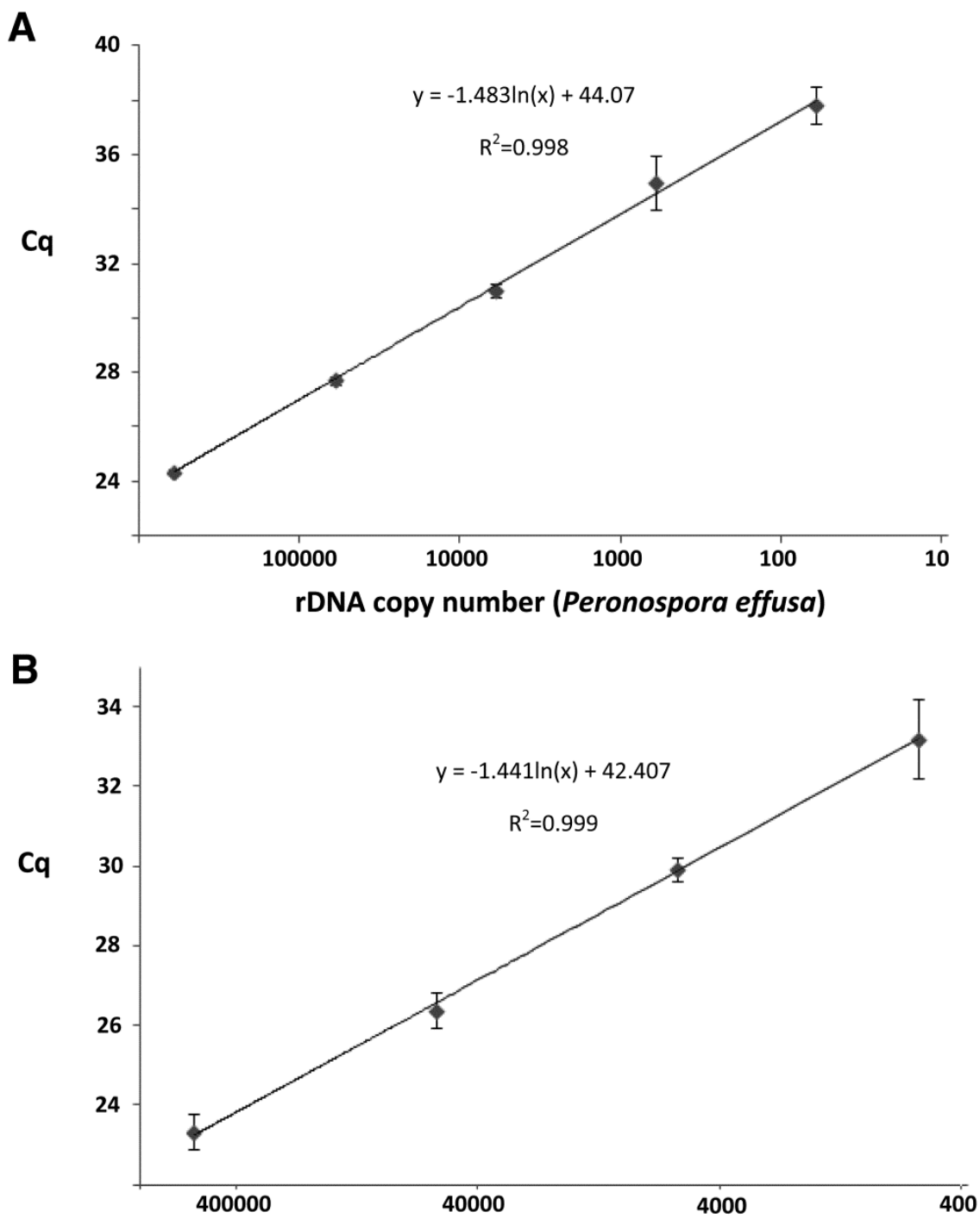

rDNA copy number (Peronospora schachtii)

Fig. 2. Standard curves for the quantification of the $18 \mathrm{~S}$ ribosomal DNA fragment (rDNA copy number) from the downy mildew pathogens Peronospora effusa and P. schachtii of spinach and Beta vulgaris, respectively. A, Five-point standard curve based on TaqMan assay amplification of plasmid DNA containing a single copy of the 18S ribosomal RNA (rRNA) gene fragment from P. effusa. Copy dilution was from 600,000 to 60 copies. B, Four-point standard curve based on TaqMan assay amplification of plasmid DNA containing a single copy of the 18S rRNA gene fragment from P. schachtii. In both A and B, the log rDNA copy number is plotted against the quantification cycle $(\mathrm{Cq})$ values. All data points are from an average of three technical replicates. 
fication of rDNA and counts of spores obtained from light microscopy (Fig. 5). Removal of one outlier (Fig. 5, marked with the arrow) resulted in a coefficient of determination $\left(R^{2}\right)=0.8644$. Using either standard curve estimate, application of the qPCR assay on spore trap samples yielded detection values corresponding to $>200$ spores of $P$. effusa on half of the dates tested (5 of 10), when the traps were placed adjacent to the infected spinach field (Table 2, copy number values $>575,000$ ). Within the same period, spore traps set at the separate Salinas location, without a nearby spinach field, yielded $<20$ spores per sampling rod (Table 2, copy number values $<20,000$ ). In contrast to the high copy numbers recorded for the Soledad trap site, the maximum copy number recorded for the Salinas site was well below 20,000 copy number $(<2,339)$ on 20 March 2013 (Table 2).

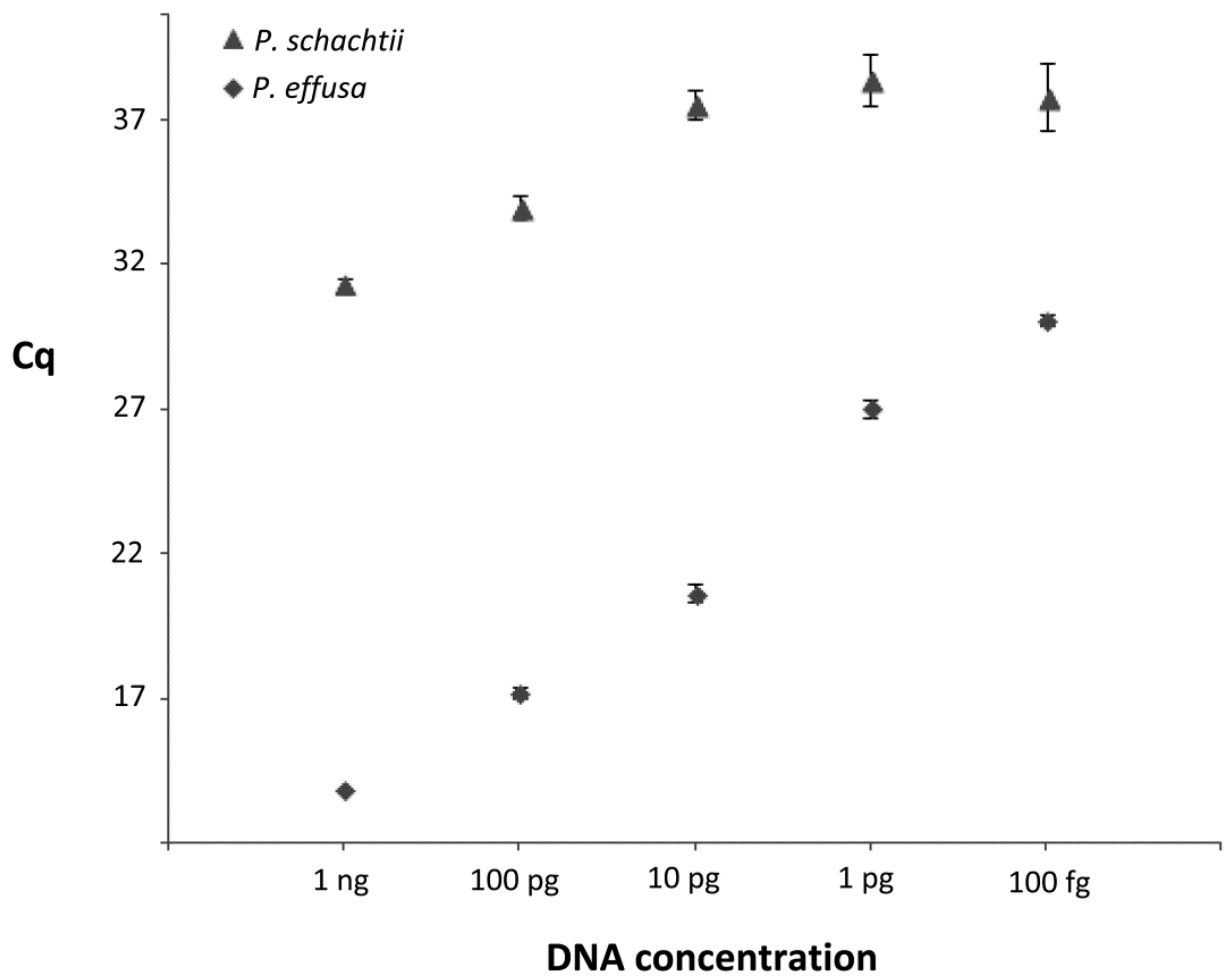

Fig. 3. Nonspecific amplification of the rDNA $18 \mathrm{~S}$ ribosomal RNA gene fragment of Peronospora schachtii when using the TaqMan assay designed for specific detection of Peronospora effusa. Quantification cycle $(\mathrm{Cq})$ values were obtained from the amplification of purified plasmid DNA at the concentrations indicated from $P$. effusa and P. schachtii. The P. effusa-specific probe Pbe1 and primer PeR1 and nonspecific primer AS1 were used for all reactions. Error bars are \pm standard deviation from three technical replicates.

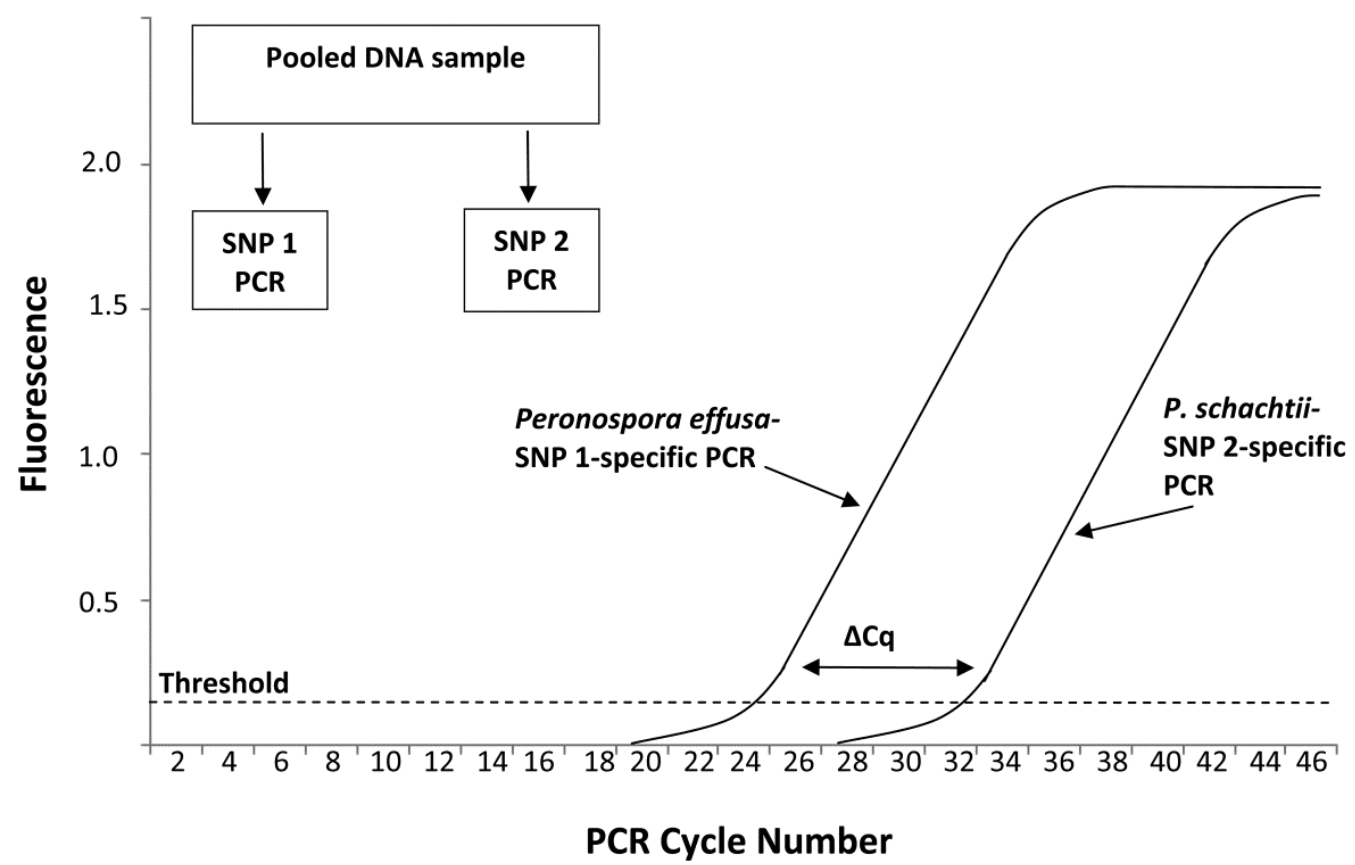

Fig. 4. Illustration of Peronospora-single-nucleotide polymorphism (SNP)-specific polymerase chain reaction to determine the frequency of amplification of the 18 S ribosomal DNA sequence of Peronospora effusa or $P$. schachtii. The illustration is adapted from Germer et al. (23) and reproduced with permission from Cold Spring Harbor Laboratory Press. 
Analyses of qPCR inhibition. Inhibition of the TaqMan assay with the $P$. effusa-specific probe and $P$. effusa genomic DNA as template was detected in the presence of grease-coated spore trap rods. This inhibition was detected whether or not DNA was extracted from a single spore trap rod with a single elution of buffer volume, or from two spore trap rods in which the DNA extract was eluted through the column twice with the same extraction buffer volume (Table 3). However, the level of qPCR inhibition was reduced by $\approx 1 \mathrm{Cq}$ value using a single rod with a single elution of the silica membrane spin column with buffer, rather than elution of two membranes with the same buffer volume (Table 3). Because of evidence of qPCR inhibition by spore trap grease, all the copy number values were adjusted by changing the threshold to the efficiency of the $P$. effusa genomic DNA standard curve plus inhibitors (91.6\%; data not shown). All of the copy numbers shown in Table 2 represent these adjusted values.

\section{DISCUSSION}

The primary objectives of this study were to develop a realtime qPCR assay for $P$. effusa and to apply the assay for detection of $P$. effusa on impaction spore trap samples. In the process, the rDNA gene and ITS sequences were compared for the devel- opment of TaqMan probes to differentiate $P$. effusa from related oomycetes. Because of the high sequence identity between rDNA sequences of $P$. effusa and $P$. schachtii, employment of SNP allele-frequency determination by qPCR $(4,23)$ allowed calculations of the frequency of $P$. effusa and $P$. schachtii on impaction spore trap samples collected from the field.

Individual probes and reverse primers were designed for detection of each pathogen, $P$. schachtii and $P$. effusa, taking advantage of a SNP identified in the $18 \mathrm{~S}$ rDNA target sequence. Even with the SNP differences incorporated into the probe and reverse primer, nonspecific amplification of the target rDNA was detected from $P$. effusa- or $P$. schachtii-infected leaf samples or purified DNA. This necessitated subtraction of nonspecific amplification of one assay from the other TaqMan assay. This need arose especially in view of the findings that $P$. schachtii does not infect spinach $(8,27$, and results from this study) and that $B$. vulgaris subsp. vulgaris is grown in a range that closely overlaps that of spinach production in California. The presence of $P$. schachtii could potentially interfere with an assay designed for specific detection of $P$. effusa, which only causes downy mildew on spinach (8).

Nonspecific amplification may be negligible from impaction spore trap samples, such as at the Soledad trap site, where high copy numbers of $P$. effusa rDNA were recorded. In these in-

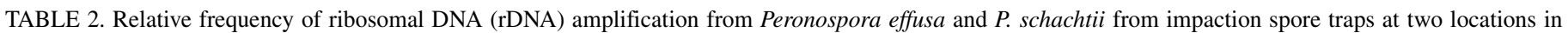
the Salinas Valley, CA

\begin{tabular}{|c|c|c|c|c|c|c|}
\hline $\begin{array}{l}\text { Sample } \\
\text { location }^{\mathrm{a}}\end{array}$ & $\begin{array}{c}\text { Date of sample } \\
\text { collection }\end{array}$ & $\begin{array}{l}P . \text { effusa } \\
\mathrm{Cq} \pm \mathrm{SD}^{\mathrm{b}}\end{array}$ & $\begin{array}{l}\text { P. schachtii } \\
\mathrm{Cq} \pm \mathrm{SD}\end{array}$ & $\begin{array}{c}\text { Frequency } \\
P \text {. effusa }\end{array}$ & $\begin{array}{l}\text { Frequency } \\
\text { P. schachtii }\end{array}$ & $\begin{array}{l}\text { DNA copy number } \\
(P . \text { effusa } 18 \mathrm{~S} \text { rDNA })^{\mathrm{c}}\end{array}$ \\
\hline Salinas & March 13 & $37.33 \pm 1.52$ & $34.24 \pm 0.15$ & 0.01 & 0.99 & 2 \\
\hline Salinas & - & $35.34 \pm 0.41$ & $29.67 \pm 0.36$ & 0.00 & 1.00 & 0 \\
\hline Soledad $^{1}$ & - & $30.04 \pm 0.15$ & NA & 1.00 & 0.00 & 18,129 \\
\hline Soledad $^{2}$ & - & $29.15 \pm 0.26$ & $34.40 \pm 4.48$ & 0.98 & 0.02 & 31,683 \\
\hline Salinas & March 15 & $36.42 \pm 1.17$ & $38.60 \pm 0.00$ & 0.99 & 0.01 & 282 \\
\hline Salinas & - & $37.90 \pm 1.05$ & NA & 1.00 & 0.00 & 109 \\
\hline Soledad $^{1}$ & - & $24.91 \pm 0.14$ & $36.85 \pm 0.44$ & 1.00 & 0.00 & 508,689 \\
\hline Soledad $^{2}$ & - & $23.39 \pm 0.43$ & $35.44 \pm 0.41$ & 1.00 & 0.00 & $1,368,163$ \\
\hline Salinas & March 18 & NA & $36.06 \pm 0.32$ & 0.00 & 1.00 & 0 \\
\hline Salinas & - & NA & NA & 0.00 & 0.00 & 0 \\
\hline Soledad $^{1}$ & - & $28.45 \pm 0.28$ & $35.69 \pm 0.08$ & 0.99 & 0.01 & 50,359 \\
\hline Soledad $^{2}$ & - & $23.01 \pm 0.14$ & $28.57 \pm 1.15$ & 0.98 & 0.02 & $1,711,320$ \\
\hline Salinas & March 20 & $31.48 \pm 0.33$ & $30.49 \pm 0.75$ & 0.33 & 0.67 & 2,339 \\
\hline Salinas & - & $35.37 \pm 0.91$ & $31.72 \pm 0.92$ & 0.07 & 0.93 & 39 \\
\hline Soledad $^{1}$ & - & $21.36 \pm 0.49$ & $30.97 \pm 0.53$ & 1.00 & 0.00 & $5,131,043$ \\
\hline Soledad $^{2}$ & - & $21.71 \pm 0.61$ & $30.53 \pm 0.00$ & 1.00 & 0.00 & $4,073,110$ \\
\hline Salinas & March 22 & $37.31 \pm 0.00$ & NA & 1.00 & 0.00 & 159 \\
\hline Salinas & - & $36.06 \pm 0.65$ & $36.60 \pm 1.51$ & 0.59 & 0.41 & 212 \\
\hline Soledad $^{1}$ & $-^{\mathrm{d}}$ & $31.69 \pm 1.31$ & $32.15 \pm 0.00$ & 0.58 & 0.42 & 3,592 \\
\hline Salinas & March 25 & $34.51 \pm 0.00$ & $34.51 \pm 0.00$ & 0.50 & 0.50 & 494 \\
\hline Salinas & - & $34.61 \pm 1.96$ & $30.56 \pm 0.37$ & 0.05 & 0.95 & 46 \\
\hline Soledad $^{1}$ & - & $26.94 \pm 0.40$ & $35.01 \pm 0.00$ & 1.00 & 0.00 & 135,353 \\
\hline Soledad $^{2}$ & - & $27.05 \pm 0.47$ & $36.43 \pm 0.64$ & 1.00 & 0.00 & 126,327 \\
\hline Salinas & March 27 & $36.51 \pm 0.00$ & NA & 1.00 & 0.00 & 269 \\
\hline Salinas & - & $36.91 \pm 0.00$ & $36.91 \pm 0.00$ & 0.05 & 0.95 & 207 \\
\hline Soledad $^{1}$ & - & $32.66 \pm 0.72$ & $39.52 \pm 0.00$ & 0.98 & 0.02 & 95,593 \\
\hline Soledad $^{2}$ & - & $36.02 \pm 1.43$ & $36.88 \pm 0.32$ & 0.65 & 0.35 & 11,492 \\
\hline Salinas & March 29 & $32.92 \pm 0.25$ & $29.27 \pm 0.63$ & 0.07 & 0.93 & 194 \\
\hline Salinas & - & $35.58 \pm 1.40$ & $30.51 \pm 0.04$ & 0.03 & 0.07 & 15 \\
\hline Soledad $^{1}$ & - & $28.04 \pm 0.29$ & $37.72 \pm 0.21$ & 1.00 & 0.00 & 66,285 \\
\hline Soledad $^{2}$ & - & $27.08 \pm 0.28$ & $37.11 \pm 0.41$ & 1.00 & 0.00 & 123,627 \\
\hline Salinas & April 1 & $34.43 \pm 0.47$ & $29.38 \pm 0.41$ & 0.03 & 0.97 & 31 \\
\hline Salinas & - & $32.82 \pm 0.38$ & $29.65 \pm 0.30$ & 0.10 & 0.90 & 297 \\
\hline Soledad $^{1}$ & - & $23.68 \pm 0.41$ & $32.48 \pm 0.42$ & 1.00 & 0.00 & $1,131,390$ \\
\hline Soledad $^{2}$ & - & $26.02 \pm 0.62$ & $36.32 \pm 0.69$ & 1.00 & 0.00 & 246,283 \\
\hline Salinas & April 3 & $36.37 \pm 0.00$ & $32.48 \pm 0.72$ & 0.06 & 0.94 & 18 \\
\hline Salinas & - & NA & NA & 0.00 & 0.00 & 0 \\
\hline Soledad $^{1}$ & - & $27.81 \pm 0.48$ & $31.33 \pm 1.61$ & 0.92 & 0.08 & 71,063 \\
\hline Soledad $^{2}$ & - & $29.50 \pm 0.22$ & $34.97 \pm 0.00$ & 0.98 & 0.02 & 25,239 \\
\hline
\end{tabular}

${ }^{\text {a }} \mathrm{Cq}=$ quantification cycle, $\mathrm{SD}=$ standard deviation calculated with three technical replicates, and NA = no amplification recorded.

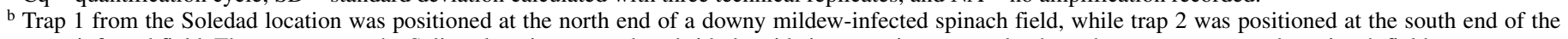
same infected field. The two traps at the Salinas location were placed side-by-side in an equipment yard, where there was not a nearby spinach field.

c Derived from frequency $P$. effusa $\times$ total $18 \mathrm{~S}$ DNA copy number for each reaction.

$\mathrm{d}$ There was a single sample collected from the Soledad location on March 22 because impaction spore trap rods were missing from trap 2. 
stances, the amount of nonspecific $P$. effusa or $P$. schachtii DNA present per reaction would be reduced substantially. Nevertheless, rather than using a $\mathrm{Cq}$ cut-off limit for each primer-probe set, individual PCRs from the pooled DNA sample (i.e., spore traps) would be advisable for testing the amount of rDNA amplification from either pathogen. For example, Cq values of $31.48 \pm 0.33 \mathrm{SD}$ and $30.49 \pm 0.75 \mathrm{SD}$ were recorded for $P$. effusa and $P$. schachtii, respectively, on the same date (20 March 2103) at the same sampling site (Salinas). These $\mathrm{Cq}$ values reflect similar quantities of each of the pathogens on that date; therefore, nonspecific amplification must be taken into account.

The TaqMan assays were designed for specific amplification of the rDNA of $P$. effusa or $P$. schachtii. However, all leaf samples infected with $P$. rumicis tested positive using the $P$. schachtiispecific assay, and one of three samples infected with $P$. bonihenrici was positive when tested using the $P$. schachtii-specific assay. Although the $P$. schachtii-specific TaqMan assay showed nonspecificity in the amplification of DNA of two other Peronospora spp., this may not affect the assay specificity in the geographic regions of interest for the following reason. The hosts for these two pathogens, $R$. acetosa (garden sorrel, in the family Polygonaceae) and C. bonus-henricus (good King Henry, in the family Chenopodiaceae), respectively, are the only two host plants tested in this study that have not been reported in the states of California or Arizona in the western United States (USDA Natural Resources Conservation Service, National Plant Data; http://plants.usda.gov). Therefore, these particular pathogens should not interfere with specificity of detection of $P$. schachtii in these states. $P$. schachtii is phylogenetically close to $P$. rumicis (13) and likely explains the cross-reactivity using the $P$. schachtiispecific probe and primer set. In contrast, the $P$. effusa-specific TaqMan assay allowed for the differentiation of $P$. effusa from other downy mildew pathogens infecting various other plant hosts. The testing of additional primer sets and sequences to delineate intra- or interspecific variation within and between $P$. effusa and $P$. schachtii based upon geographic origin, or even races of the pathogen, may be highly informative. Analyses of mitochondrial sequences have revealed intraspecific differentiation of $P$. effusa (14), which could probably also help to further delineate the closely related species of Chenopodiaceae, including $P$. effusa, $P$. schachtii, and $P$. rumicis.

The pathogenicity tests on the differential spinach cultivars using downy-mildew-infected samples obtained from other plants in the family Chenopodiaceae indicate that downy mildew on those hosts does not contribute to downy mildew observed on spinach. These samples included those from locally collected

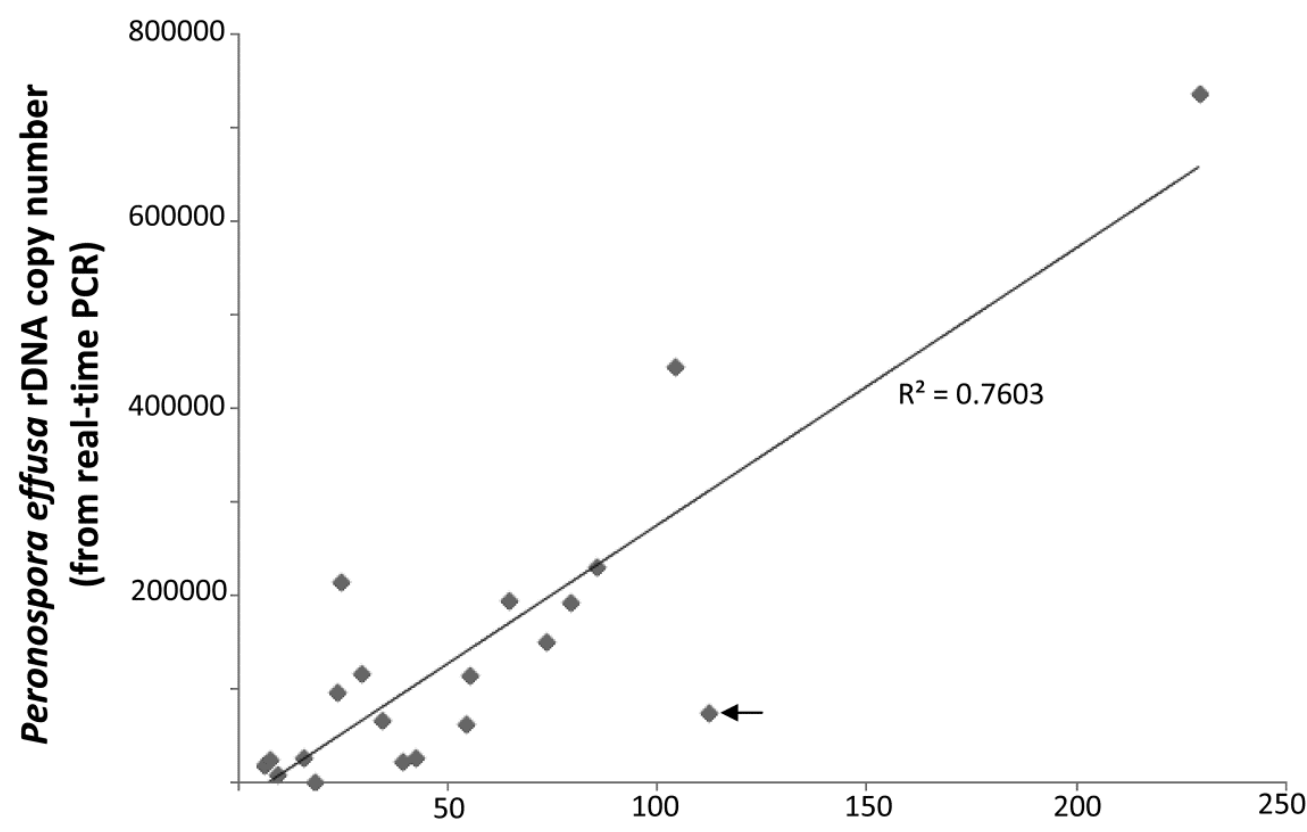

Peronospora effusa spores (counted by microscopy)

Fig. 5. Correlation between DNA copy number of Peronospora effusa derived from a standard curve of the amplification of ribosomal DNA (rDNA) with counts of spores obtained from light microscopy. The equation for the line with $R^{2}=0.7603$ is $y=2960.4 x-20261$. Removal of a single outlier (112 spores; marked by the arrow) resulted in $R^{2}=0.864$.

TABLE 3. Analyses of quantitative polymerase chain reaction inhibition using DNA of Peronospora effusa and the $P$. effusa-specific TaqMan assay in the absence (No extract) or presence $(2 \times$ or $1 \times$ elution) of grease-coated spore trap rods

\begin{tabular}{|c|c|c|c|c|}
\hline DNA concentration & $\mathrm{Cq} \pm \mathrm{SD}(\text { no extract })^{\mathrm{a}}$ & $\mathrm{Cq}(2 \times$ elution, 2 rods $)$ & $\mathrm{Cq}(1 \times$ elution, 1 rod $)$ & $\mathrm{Cq}$ difference ${ }^{\mathrm{b}}$ \\
\hline $100 \mathrm{pg}^{\mathrm{c}}$ & $24.80 \pm 0.70$ & $27.04 \pm 0.48$ & $\ldots$ & 2.24 \\
\hline $1 \mathrm{pg}$ & $31.39 \pm 0.08$ & $33.53 \pm 0.07$ & $\ldots$ & 2.14 \\
\hline $10 \mathrm{pg}$ & $27.79 \pm 0.32$ & $\ldots$ & $28.76 \pm 0.36$ & 0.97 \\
\hline $1 \mathrm{pg}$ & $30.53 \pm 0.60$ & $\ldots$ & $32.27 \pm 0.44$ & 1.74 \\
\hline $100 \mathrm{fg}$ & $33.76 \pm 0.49$ & $\ldots$ & $35.01 \pm 0.49$ & 1.25 \\
\hline
\end{tabular}

${ }^{\mathrm{a}} \mathrm{Cq}=$ quantification cycle and $\mathrm{SD}=$ standard deviation.

${ }^{\mathrm{b}}$ Difference between the average $\mathrm{Cq}$ values of three technical replicates.

c Separate standard curves were prepared at the indicated concentrations of genomic DNA. 
downy-mildew-infected weed (C. album, lambsquarters) and crop (D. ambrosioides, epazote) plants in Monterey County or neighboring Santa Cruz County. Previous studies $(8,27)$ and related studies reviewed therein also indicate that both $P$. effusa and $P$. schachtii are host specific. Taken together, these results are highly informative for development of assays designed to detect and quantify the amounts of airborne inoculum from these pathogens that contribute to disease outbreaks only on spinach or beet. Also, in agreement with previous results $(8,27)$, downy mildew from cultivated beet did not cause disease on spinach in this study.

Among the potential drawbacks of qPCR strategies for disease forecasting, qPCR detects DNA from both live and dead spores. However, given the adaptations of windborne pathogens for the dissemination of short-lived spores, the most important increases of airborne inoculum during a growing season are likely derived almost entirely from live spores (35). The use of rDNA sequences for the purpose of quantifying the amount of airborne inoculum is beneficial because the detection target is multicopy and, thus, increases sensitivity. However, the rDNA copy number varies approximately two- to threefold between isolates of fungi, such as in Verticillium dahliae (5) and Leptosphaeria maculans (32), and probably in the oomycetes as well. Nevertheless, in the case of L. maculans, the amount of ITS DNA amplified was proportional to the numbers of ascospores (32). The results of this current study also indicate that the amount of $P$. effusa rDNA amplified is proportional to the amount of $P$. effusa spores counted by microscopy. Furthermore, for airborne inoculum of Peronospora spp., the average rDNA copy number (between isolates within a population) is likely the number of most relevance for predictive purposes.

Inhibition of PCR in DNA extracts may increase false-negative readings and could detrimentally affect a qPCR results by reducing amplification efficiency. DNA purification with commercial kits and dilution of the DNA extract can minimize the effect of inhibitors on PCRs (7). The findings herein of spore trap greasemediated qPCR inhibition indicate the importance of factoring in the amount of qPCR inhibition to accurately assess target DNA copy number in environmental sampling. Importantly, qPCR inhibition was decreased by reducing the number of buffer passes through the silica membrane column used with the Nucleospin DNA extraction kit (Machery-Nagel).

The TaqMan assays developed herein are sensitive detection tools for the downy mildew pathogens of spinach and B. vulgaris subsp. vulgaris. The total DNA content per nucleus for Peronospora spp. was previously estimated at 47 to $138 \mathrm{fg}$ (34). The detection sensitivity limit of $10 \mathrm{fg}$ using the TaqMan assays for $P$. effus $a$ and $P$. schachtii suggested that the amounts of genomic DNA corresponding to a single spore were detectable. Although the focus of this research was on the development and deployment of a detection assay for $P$. effusa, known numbers of spores of both species could also be calculated from spore trap samples. These sensitive tools are projected to provide data on patterns of windborne inoculum levels in the Salinas Valley and to yield insights on the environmental conditions that favor outbreaks of downy mildew.

Predictions based on the optimal conditions favoring disease have been used for the timing of fungicide applications for the cucumber downy mildew pathogen Pseudoperonospora cubensis (22). Similarly, knowledge acquired for forecasting grape powdery mildew caused by E. necator may be useful in reducing the number of fungicide applications per growing season (17). As noted for other spore-trapping systems deployed for the purpose of disease forecasting (10), a future challenge will be in determining relationships between inoculum amount and disease development. To assess these relationships, spore trap data collection and analyses from multiple locations within the Salinas Valley, CA are currently underway.

\section{ACKNOWLEDGMENTS}

We thank W. Mahafee (USDA-ARS, Corvallis, OR) for providing materials for spore traps and advice, L. Ochoa (USDA-ARS, Salinas, CA) for collecting spore trap samples, S. Jimenez (Hartnell College, Salinas, CA) for counting spores, K. Richardson (USDA-ARS, Salinas, CA) for providing several Peronospora-infected beet tissue samples, and the California Leafy Greens Research Program for funding. H. Voglmayr acknowledges financial support by the Austrian Science Fund (FWF; project P22739-B20). Mention of trade names or commercial products in this publication is solely for the purpose of providing specific information and does not imply recommendation or endorsement by the United States Department of Agriculture (USDA). USDA is an equal opportunity provider and employer.

\section{LITERATURE CITED}

1. Altschul S. F., Gish, W., Miller, W., Myers, E. W., and Lipman, D. J. 1990. Basic local alignment search tool. J. Mol. Biol. 215:403-410.

2. Anonymous. 2013. United States Department of Agriculture, National Agricultural Statistics Service (NASS). Vegetables, 2012. Summary. U.S. Government Printing Office, Washington, DC.

3. Belbahri, L., Calmin, G., Pawlowski, J., and Lefort, F. 2005. Phylogenetic analysis and real time PCR detection of a presumably undescribed Peronospora species on sweet basil and sage. Mycol. Res. 109:12761287.

4. Billard, A., Laval, V., Fillinger, S., Leroux, P., Lachaise, H., Beffa, R., and Debieu, D. 2012. The allele-specific probe and primer in amplification assay, a new real-time PCR method for fine quantification of singlenucleotide polymorphisms in pooled DNA. Appl. Environ. Microbiol. 78:1063-1068.

5. Bilodeau, G. J., Koike, S. T., Uribe, P., and Martin, F. N. 2012. Development of an assay for rapid detection and quantification of Verticillium dahliae in soil. Phytopathology 102:331-343.

6. Blanco-Meneses, M., and Ristaino, J. B. 2011. Detection and quantification of Peronospora tabacina using a real-time polymerase chain reaction assay. Plant Dis. 95:673-682.

7. Brandfass, C., and Karlovsky, P. 2008. Upscaled CTAB-based DNA extraction and real-time PCR assays for Fusarium culmorum and Fusarium graminearum DNA in plant material with reduced sampling error. Intl. J. Mol. Sci. 9:2306-2321.

8. Byford, W. J. 1967. Host specialization of Peronospora farinosa on Beta, Spinacia and Chenopodium. Trans. Br. Mycol. Soc. 50:603-607.

9. Calderon, C., Ward, E., Freeman, J., Foster S. J., and McCartney, H. A. 2002. Detection of airborne inoculum of Leptosphaeria maculans and Pyrenopezziza brassicae in oilseed rape crops by polymerase chain reaction (PCR) assays. Plant Pathol. 51:303-310.

10. Carisse, O., Savary, S., and Willocquet, L. 2008. Spatiotemporal relationships between disease development and airborne inoculum in unmanaged and managed Botrytis leaf blight epidemics. Phytopathology 98:38-44.

11. Carisse, O., Tremblay, D. M., Lévesque, C. A., Gindro, K., Ward, P., and Houde, A. 2009. Development of a TaqMan real-time PCR assay for quantification of airborne conidia of Botrytis squamosa and management of Botrytis leaf blight of onion. Phytopathology 99:1273-1280.

12. Choi, Y.-J., Denchev, C. M., and Shin, H.-D. 2008. Morphological and molecular analyses support the existence of host-specific Peronospora species infecting Chenopodium. Mycopathologia 165:155-164.

13. Choi, Y.-J., Hong, S.-B., and Shin, H.-D. 2007. Re-consideration of Peronospora farinosa infecting Spinacia oleracea as distinct species, Peronospora effusa. Mycol. Res. 111:381-391.

14. Choi, Y.-J., Thines, M., Han, J. G., and Shin, H.-D. 2011. Mitochondrial phylogeny reveals intraspecific variation in Peronospora effusa, the spinach downy mildew pathogen. J. Microbiol. 49:1039-1043.

15. Constantinescu, O. 1991. An annotated list of Peronospora names. Thunbergia 15:1-110.

16. Correll J. C., Bluhm, B. H., Feng, C., Lamour, K., du Toit, L. J., and Koike, S. T. 2011. Spinach: Better management of downy mildew and white rust through genomics. Eur. J. Plant Pathol. 129:193-205.

17. Falacy, J. S., Grove, G. G., Mahaffee, W. F., Galloway, H., Glawe, D. A., Larsen, R. C., and Vandermark, G. J. 2007. Detection of Erysiphe necator in air samples using the polymerase chain reaction and species-specific primers. Phytopathology 97:1290-1297.

18. Feng, C., Correll, J. C., Kammeijer, K. E., and Koike, S. T. 2014. Identification of new races and deviating strains of the spinach downy mildew pathogen Peronospora farinosa f. sp. spinaciae. Plant Dis. 98:145-152.

19. Fraaije, B. A. Cools, H. J., Fountaine, J., Lovell, D. J., Motteram, J., West, 
J. S., and Lucas, J. A. 2005. Role of ascospores in further spread of QoIresistant cytochrome $\mathrm{b}$ alleles (G143A) in field populations of Mycosphaerella graminicola. Phytopathology 95:933-941.

20. Fuckel, L. 1866. Fungi rhenani (Fortsetzung). Hedwigia 5:23-30.

21. Gent, D. H., Mahaffee, W. F., McRoberts, N., and Pfender, W. F. 2013. The use and role of predictive systems in disease management. Annu. Rev. Phytopathol. 51:267-289.

22. Gent, D. H., Nelson, M. E., Farnsworth, J. L., and Grove, G. G. 2009. PCR detection of Pseudoperonospora humuli in air samples from hop yards. Plant Pathol. 58:1081-1091.

23. Germer, S., Holland, M. J., and Higuchi, R. 2000. High-throughput SNP allele-frequency determination in pooled DNA samples by kinetic PCR. Genome Res. 10:258-266.

24. Kim, J. Y., Choi, Y.-J., and Shin, H. D. 2010. Downy mildew caused by Peronospora farinosa f. sp. betae newly reported on Swiss chard in Korea. Plant Pathol. 59:405.

25. Landa, B. B., Montes-Borrego, M., Munoz-Ledesma, F. J., and JimenezDiaz, R. M. 2007. Phylogenetic analysis of downy mildew pathogens of opium poppy and PCR-based in planta and seed detection of Peronospora arborescens. Phytopathology 97:1380-1390.

26. Lange, W., Brandenburg, W. A., and De Bock, T. S. M. 1999. Taxonomy and cultonomy of beet (Beta vulgaris L.) Bot. J. Linn. Soc. 130:81-96.

27. Leach, L. D. 1931. Downy mildew of the beet, caused by Peronospora schachtii Fuckel Hilgardia 6:203-251.

28. Riethmuller, A., Voglmayr, H., Göker, M., WeiB, M., and Oberwinkler, F. 2002. Phylogenetic relationships of the downy mildews (Peronosporales) and related groups based on nuclear large subunit ribosomal DNA sequences. Mycologia 94:834-849.

29. Rogers, S. L., Atkins, S. D., and West, J. S. 2009. Detection and quantification of airborne inoculum of Sclerotinia sclerotiorum using quantitative PCR. Plant Pathol. 58:324-331.

30. Schweigkofler, W., O'Donnell, K., and Garbelotto, M. 2004. Detection and quantification of airborne conidia of Fusarium circinatum, the causal agent of pine pitch canker, from two California sites by using a real-time PCR approach combined with a simple spore trapping method. Appl. Environ. Microbiol. 70:3512-3520.

31. Urbez-Torres, J. R., Battany, M., Bettiga, L. J., Gispert, C., McGourty, G., Roncoroni, J., Smith, R. J., Verdegaal P., and Gubler, W. D. 2010. Botryosphaeriaceae species spore-trapping studies in California vineyards. Plant Dis. 94:717-724.

32. Van de Wouw, A. P., Stonard, J. F., Howlett, B. J., West, J. S., Fitt, B. D. L., and Atkins, S. D. 2010. Determining frequencies of avirulent alleles in airborne Leptosphaeria maculans inoculum using quantitative PCR. Plant Pathol. 59:809-818.

33. Voglmayr, H. 2003. Phylogenetic relationships of Peronospora and related genera based on nuclear ribosomal ITS sequences. Mycol. Res. 107:1132-1142.

34. Voglmayr, H., and Greilhuber, J. 1998. Genome size determination in Peronosporales (Oomycota) by feulgen image analysis. Fungal Genet. Biol. 25:181-195.

35. West, J. S., Atkins, S. D., Emberlin, J., and Fitt, B. D. 2008. PCR to predict risk of airborne disease. Trends Microbiol. 16:380-387.

36. Yerkes, W. D., and Shaw, C. G. 1959. Taxonomy of the Peronospora species on Cruciferae and Chenopodiaceae. Phytopathology 49:499-507. 